FENOMENA PEMAHAMAN DAN PENERAPAN HAKIKAT MAKNA KATA KEJAHATAN DAN PELANGGARAN DALAM PERKEMBANGAN HUKUM

Hamsir

$\mathrm{OO}$

IJTIHAD DAN URGENSINYA

Usman Jafar

$\longrightarrow 0$

PARTISIPASI POLITIK DALAM KONSEPSI TEORI PILIHAN RASIONAL JAMES S COLEMAN

Nila Sastrawati

THAHARAH LAHIR DAN BATIN DALAM AL-QURAN

(Penafsiran terhadap Qs. Al-Muddatsir/74:4 dan Qs. Al-Maidah/5:6)

Ahmad Mujahid, Haeriyyah

$-10$

STUDI KRITIS PERNIKAHAN BAWAH UMUR PERSPEKTIF UUP NO. 16 TAHUN 2019 DAN GENDER ANALISIS

Sippah Chotban

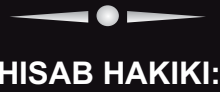

Metode IImiah Penentuan Awal Bulan Kamariyah

Alimuddin

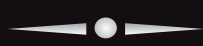

POLIGAMI DALAM SOROTAN

(Kajian Kitab-kitab Tafsir Modern/Kontemporer)

Halimah B

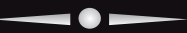

ADAT AMPIKALE:

Asuransi Ala Masyarakat Bugis di Kecamatan Pammana Kabupaten Wajo

Hadi Daeng Mapuna

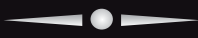

MEDIA SOSIAL DAN DAMPAKNYA TERHADAP PERCERAIAN

Sohrah

זע: HIMPUNAN ILMUWAN DAN SARJANA SYARIAH INDONESIA 


\section{$\underline{\text { Al-Risalah }}$}

Jurnal Ilmu Syariah dan Hukum

\section{DAFTAR ISI}

FENOMENA PEMAHAMAN DAN PENERAPAN HAKIKAT MAKNA KATA

KEJAHATAN DAN PELANGGARAN DALAM PERKEMBANGAN HUKUM

Hamsir

IJTIHAD DAN URGENSINYA

Usman Jafar

PARTISIPASI POLITIK DALAM KONSEPSI TEORI PILIHAN

RASIONAL JAMES S COLEMAN

Nila Sastrawati

THAHARAH LAHIR DAN BATIN DALAM AL-QURAN

(Penafsiran terhadap Qs. Al-Muddatsir/74:4 dan Qs. Al-Maidah/5:6)

Ahmad Mujahid, Haeriyyah

STUDI KRITIS PERNIKAHAN BAWAH UMUR PERSPEKTIF UUP NO. 16

TAHUN 2019 DAN GENDER ANALISIS

Sippah Chotban

HISAB HAKIKI: Metode Ilmiah Penentuan Awal Bulan Kamariyah

Alimuddin

POLIGAMI DALAM SOROTAN (Kajian Kitab-kitab Tafsir

Modern/Kontemporer)

Halimah B 
PERILAKU SEKSUAL TRANSGENDER

254-275

(Studi Komparatif Hak Asasi Manusia Antara Perspektif The Universal

Declaration of Human Right dan The Cairo Declaration of Human Right)

Adriana Mustafa

ADAT AMPIKALE: Asuransi Ala Masyarakat Bugis di Kecamatan Pammana

Kabupaten Wajo

276-285

Hadi Daeng Mapuna

MEDIA SOSIAL DAN DAMPAKNYA TERHADAP PERCERAIAN

286-296

Sohrah 


\title{
PARTISIPASI POLITIK DALAM KONSEPSI TEORI PILIHAN RASIONAL JAMES S COLEMAN
}

\author{
Nila Sastrawati \\ Fakultas Syariah dan Hukum UIN Alauddin Makassar
}

\section{Abstract}

Social action is an important aspect in analyzing behavior, including in analyzing the political participation of individuals and society. Diverse forms of political participation indicate that individuals make choices of political participation based on subjective considerations with reference to costs and rewards. In the conception of Rational Choice Theory from James S. Coleman, there are 2 main essences, namely actors and resources. Actors as actors of participation, have the power to use resources, including external resources or political modalities so that the actors' political objectives are achieved.

Keywords: Political Participation, Rational Choice, Actors, Resources

\section{A. PENDAHULUAN}

Diskursus politik akan terus berubah seiring dengan perubahan sosial yang terjadi dalam masyarakat. Perubahan berimplikasi pada sikap dan tindakan sebagai entitas yang dinamis pada seluruh aspek kehidupan masyarakat termasuk dalam aspek politik. Peningkatan pengetahuan dan informasi yang dimiliki masyarakat secara keseluruhan pada gilirannya mengarah kepada kekayaan intelektual dan bertransformasi menjadi aspirasi pemikiran politik baru sebagai dasar dari motivasi dan orientasi politik individu.

Keterlibatan masyarakat dalam politik merupakan salah satu indikator ketercapaian asas demokrasi. Tiada demokrasi tanpa partisipasi politik warga, sebab partisipasi merupakan esensi dari demokrasi. Partisipasi atau keterlibatan masyarakat dalam berpolitik merupakan ukuran demokrasi suatu negara ${ }^{1}$. Negara demokrasi menempatkan partisipasi politik rakyat sebagai salah satu kunci pokok keberhasilan negara. Negara dengan tingkat partisipasi politik yang tinggi menunjukkan bahwa warga negara memahami pentingnya keterlibatan politik dengan bersedia melibatkan diri di dalam kegiatankegiatan tersebut. Asumsi yang terbangun bahwa masyarakat yang lebih tahu apa yang dibutuhkan dalam kehidupan sosial dan bernegara.

Partisipasi masyarakat dan politik atau pembangunan juga menjadi pembahasan tersendiri dalam sejarah Islam kontemporer. Mengenai hal tersebut, Yusuf al Qadrawi mengemukakan bahwa negara (kekuasaan politik) diperlukan oleh umat Islam sebagai instrumen untuk menjamin dan melaksanakan syari'ah, baik aqidah, hukum, maupun akhlak dalam kehidupan kolektif. Negara yang merupakan perwujudan dari kekuasaan politik

\footnotetext{
${ }^{1}$ Mochtar Mas'oed, Negara, Kapital dan Demokrasi, Yogyakarta: Pustaka Pelajar, 2003, hal 43.
} 
mengatur, memberikan kebebasan dengan batasan-batasan yang jelas sehingga masyarakat mengetahui hak dan kewajibannya sebagai warga negara ${ }^{2}$.

Realitas politik menunjukkan adanya peningkatan minat politik masyarakat yang cukup signifikan. Instrumen politik antara lain keberadaan partai-partai politik membuka ruang bagi masyarakat untuk mengimplementasikan minat politiknya secara praktis. Individu diperhadapkan sejumlah bentuk partisipasi politik lain yang dapat digunakan individu sesuai dengan minat politiknya, sehingga dalam realitanya tidak ada satu pun individu yang tidak terlibat dalam aktivitas politik.

Pada perspektif sosiologi, tindakan politik merupakan bagian dari tindakan sosial, yang menunjuk pada perbuatan-perbuatan yang memiliki makna subyektif bagi pelakunya dan didorong oleh motivasi. Suatu perilaku atau tindakan dapat memiliki makna social bila makna subyektif mempengaruhi individu lain dan mengarah pada makna subyektif tersebut. Individu memiliki kemampuan melakukan tindakan melalui penetapan cara atau alat dari sejumlah pilihan alternative untuk mencapai tujuan. Sebagai subjek, individu memiliki kreativitas untuk menciptakan kondisinya dan hanya dapat dibatasi oleh kondisi di luar dirinya yang tidak dapat dikonstruksi.

Terkait hal tersebut, tulisan ini akan mengemukakan, bagaimana tindakan politik (partisipasi politik) dalam perspektif Teori Pilihan Rasional. Bagaimana unsur utama dari tindakan rasional memengaruhi tindakan politik individu. Tulisan ini bertujuan, menganalisis tindakan individu dengan pendekatan Teori Pilihan Rasional (Rational Change Theory) dari James S Coleman.

\section{B. PEMBAHASAN}

\section{Rational Change (Tindakan Rasional) James S Coleman}

Rational Change Theory (Teori Tindakan Rasional) menekankan pada tindakan perseorangan yang memiliki tujuan serta ditentukan oleh nilai. Pencetus teori tersebut, James S. Coleman (1926-1995) merupakan salah satu sosiolog paling terkemuka di paruh kedua abad kedua puluh. Dilahirkan pada tahun 1926, di Bedford, Indiana, lulus sebagai sarjana sains dari Universitas Purdue pada tahun 1949. James S. Coleman memiliki tugas sebagai insinyur kimia, dan belajar sosiologi di Universitas Columbia di New York dari tahun 1951 hingga 1955, terutama dengan Robert Merton, Paul Lazarsfeld, dan Martin Lipset. Selama masa hidupnya, ia menerbitkan 28 buku dan lebih dari 300 artikel. Publikasi yang memiliki dampak tertinggi adalah pada sosiologi komunitas dan pendidikan (sekolah), penelitian kebijakan, dan sosiologi pilihan matematika dan rasional. Setelah mendapatkan gelar PhD dalam sosiologi pada tahun 1955 (Columbia) ${ }^{3}$.

\footnotetext{
${ }^{2}$ Yusuf Al Qhardawi, Membumikan Syariat Islam (Dunia Ilmu:Surabaya,1997)

${ }^{3}$ Goerge Ritzer, Encyclopedia of Social Theory, (United Kindom America; SAGE Pbulication, 2004), h. 111
} 
Coleman mengkaji sistem sosial dimana fenomena makro harus dijelaskan oleh faktor internalnya, khususnya oleh faktor individu. pertama, sistem sosial terdiri dari individu. Meskipun individu cenderung memiliki sifat manusia yang sama, tetapi memiliki perbedaan sesuai dengan bagaimana mereka "dibentuk" dalam masyarakat, dan bagi seorang sosiolog, penting untuk memahami mekanisme yang membentuk tersebut. Coleman mengembangkan konsep "modal sosial" sebagai alat penting untuk analisis sosial. Kedua, aksi dan interaksi individu bergabung membentuk sistem sosial melalui pengembangan model pilihan rasional yang memungkinkannya untuk melacak proses yang menggabungkan interaksi ke dalam sistem otoritas, sistem kepercayaan, perilaku kolektif, dan aktor kolektif ${ }^{4}$.

Teori Pilihan Rasional Coleman ini tampak jelas dalam gagasan dasarnya bahwa tindakan perseorangan mengarah pada suatu tujuan dan tujuan tersebut adalah tindakan yang ditentukan oleh nilai atau preferensi (pilihan). Coleman menyatakan bahwa memerlukan konsep tepat mengenai aktor rasional yang berasal dari ilmu ekonomi yang melihat aktor memilih tindakan yang dapat memaksimalkan kegunaan ataupun keinginan serta kebutuhan mereka.

Ada dua unsur utama dalam teori Coleman, yaitu aktor dan juga sumber daya. Sumber daya ialah setiap potensi yang ada atau bahkan yang dimiliki. Sumber daya tersebut dapat berupa sumber daya alam, yaitu sumber daya yang telah disediakan atau potensi alam yang dimiliki dan juga sumber daya manusia, yaitu potensi yang ada dalam diri seseorang. Sedangkan aktor ialah seseorang yang melakukan sebuah tindakan. Dalam hal ini, ialah individu yang mampu memanfaatkan sumber daya dengan baik yaitu aktor. Aktor dianggap sebagai individu yang memiliki tujuan, aktor juga memiliki suatu pilihan yang bernilai dasar yang digunakan aktor untuk menentukan pilihan yaitu menggunakan pertimbangan secara mendalam berdasarkan kesadarannya, selain itu aktor juga mempunyai kekuatan sebagai upaya untuk menentukan pilihan dan tindakan yang menjadi keinginannya. Sedangkan sumber daya adalah dimana aktor memiliki kontrol serta memiliki kepentingan tertentu, sumber daya juga sebagai sesuatu yang dapat dikendalikan oleh aktor ${ }^{5}$.

Coleman juga menjelaskan mengenai interaksi antara aktor dengan sumber daya ke tingkat sistem sosial. Basis minimal untuk sistem sosial adalah tindakan dua orang aktor, dimana setiap aktor mengendalikan sumber daya yang menarik perhatian bagi pihak lain. Aktor selalu mempunyai tujuan, dan masing-masing bertujuan untuk memaksimalkan wujud dari kepentingannya yang memberikan ciri saling tergantung pada tindakan aktor tersebut. Pada kehidupan nyata, Coleman mengakui bahwa individu tidak selalu bertindak atau berperilaku rasional 6 .

\footnotetext{
${ }^{4}$ Goerge Ritzer, Encyclopedia of Social Theory, hal. 112.

${ }^{5}$ Ritzer, George, dan Douglas J. Goodman, Teori Sosiologi Modern, Edisi Revisi. (Yogyakarta: Kreasi Wacana, 2012) hal 85.

${ }^{6}$ George Ritzer, Douglas J. Goodman, Teori Sosiologi (Bantul: KREASI WACANA, 2012) hal 480 .
} 
Tetapi dalam hal ini akan sama saja apakah seorang aktor dapat bertindak dengan tepat menurut rasionalitas seperti yang biasa dibayangkan ataupun menyimpang dari cara-cara yang diamati. Tindakan rasional individu dilanjutkan dengan memusatkan perhatian pada hubungan mikro-makro, ataupun bagaimana cara hubungan tindakan individual menimbulkan perilaku sistem sosial. Teori pilihan rasional berangkat dari tujuan atau maksud aktor, tetapi pada teori ini memiliki pandangan terhadap dua pemaksa utama tindakan. Pertama adalah keterbatasan sumber daya, bagi aktor yang mempunyai sumber daya besar, maka pencapaian tujuan cenderung lebih mudah. Hal ini berkorelasi dengan biaya, pemaksa utama, dan yang kedua adalah tindakan aktor individual, tindakan aktor individual disini adalah lembaga sosial.

\section{Partisipasi Politik}

Partisipasi politik merupakan serangkaian pilihan kegiatan yang berkaitan dengan keikutsertaan dalam kehidupan politik sebagai tindakan sosial. Pada realitas politik partisipasi politik dikenal secara umum pada kegiatan yang berhubungan dengan pemilihan umum, dalam realitanya partisipasi politik memiliki bentuk yang beragam.

Miriam Budiarjo, mengemukakan pengertian partisipasi politik sebagai kegiatan seseorang atau sekelompok orang untuk ikut secara aktif dalam kehidupan politik yaitu dengan cara jalan memilih pimpinan negara secara langsung atau tidak langsung, mempengaruhi kebijakan pemerintah. Kegiatan ini mencakup tindakan seperti memberikan suara dalam pemilihan umum, menghadiri rapat umum, menjadi anggota suatu partai atau kelompok kepentingan, mengadakan hubungan dengan pejabat pemerintah atau anggota parlemen. Ramlan Surbakti mendefenisikan partisipasi politik itu sebagai kegiatan warga negara biasa dalam mempengaruhi proses pembuatan dan pelaksanaan kebijaksanaan umum dan dalam ikut menentukan pemimpin pemerintahan 7 .

Beberapa defenisi partisipasi politik yang dikemukakan para ahli dan indikatornya disimpulkan Sidi Gatara sebagai berikut:

\begin{tabular}{|l|l|l|}
\hline \multicolumn{1}{|c|}{ Tokoh/ahli } & \multicolumn{1}{|c|}{ Defenisi } & \multicolumn{1}{|c|}{ Indikator } \\
\hline $\begin{array}{l}\text { Samuel P Huntington } \\
\text { \& Jhon M Nelson }\end{array}$ & $\begin{array}{l}\text { Kegiatan warga preman } \\
\text { (private citizen) yang } \\
\text { bertujuan mempengaruhi } \\
\text { pengambilan kebijakan oleh } \\
\text { pemerintah }\end{array}$ & $\begin{array}{l}\text { - Berupa kegiatan bukan } \\
\text { sikap-sikap } \\
\text { kepercayaan } \\
\text { - Memiliki tujuan } \\
\text { mempengaruhi } \\
\text { kebijakan publik }\end{array}$ \\
& & $\begin{array}{l}\text { Dilakukan warga } \\
\text { Negara preman (biasa) }\end{array}$ \\
\hline $\begin{array}{l}\text { Michael Rush \& Philip } \\
\text { Althoff }\end{array}$ & $\begin{array}{l}\text { Keterlibatan individu sampai } \\
\text { macam-macam tingkatan di } \\
\text { dalam sistem politik }\end{array}$ & $\begin{array}{l}\text { Berwujud keterlibatan } \\
\text { individu dalam sistem } \\
\text { politik }\end{array}$ \\
\hline
\end{tabular}

\footnotetext{
${ }^{7}$ Miriam Budhiardjo, Partisipasi dan Partai Politik ( PT.Gramedia, Jakarta, 1982). hal 12.
} 


\begin{tabular}{|c|c|c|}
\hline & & $\begin{array}{l}\text { - Memiliki tingkatan- } \\
\text { tingkatan partisipasi }\end{array}$ \\
\hline Herbert Mc Closky & $\begin{array}{l}\text { Kegiatan-kegiatan sukarela } \\
\text { dari warga masyarakat } \\
\text { melalui cara mereka } \\
\text { mengambil bagian dalam } \\
\text { proses pemilihan penguasa, } \\
\text { dan secara langsung dan tidak } \\
\text { langsung dalam proses } \\
\text { pembuatan atau pembentukan } \\
\text { kebijakan umum }\end{array}$ & $\begin{array}{l}\text { - Berupa kegiatan- } \\
\text { kegiatan sukarela } \\
\text { - Dilakukan warga } \\
\text { Negara } \\
\text { - Warga Negara terlibat } \\
\text { dalam proses-proses } \\
\text { politik }\end{array}$ \\
\hline Kevin R Hardwic & $\begin{array}{l}\text { Cara-cara warga Negara } \\
\text { berupaya menyampaikan } \\
\text { kepentingan-kepentingan } \\
\text { mereka terhadap pejabat- } \\
\text { pejabat publik agar mampu } \\
\text { mewujudkan kepentingan- } \\
\text { kepentingan tersebut }\end{array}$ & 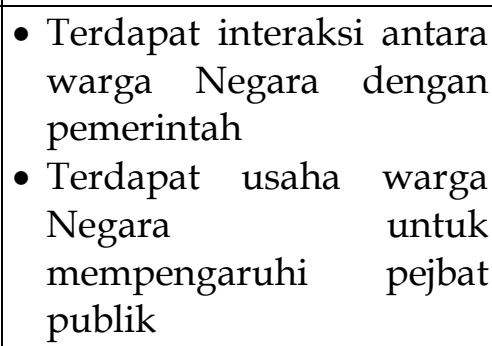 \\
\hline Miriam Budiardjo & $\begin{array}{l}\text { Kegiatan seseorang atau } \\
\text { sekelompok orang untuk ikut } \\
\text { serta secara aktif dalam } \\
\text { kehidupan politik, yakni } \\
\text { dengan cara memilih } \\
\text { pimpinan Negara, dan secara } \\
\text { langsung atau tidak langsung } \\
\text { mempengaruhi kebijakan } \\
\text { pemerintah }\end{array}$ & $\begin{array}{l}\text { - Berupa kegiatan individu } \\
\text { atau kelompok } \\
\text { - Bertujuan ikut serta } \\
\text { secara aktif dalam } \\
\text { kehidupan politik, } \\
\text { memilih pimpinan publik } \\
\text { atau mempengaruhi } \\
\text { kebijakan publik }\end{array}$ \\
\hline Ramlan Surbakti & $\begin{array}{l}\text { Keikutsertaan warga Negara } \\
\text { biasa dalam menentukan segla } \\
\text { keputusan menyangkut atau } \\
\text { mempengaruhi hidupnya }\end{array}$ & \begin{tabular}{|lr} 
- Keikutsertaan & warga \\
Negara & dalam \\
pembuatan & dan \\
pelaksanaan & kebijakan \\
publik & \\
- Dilakukan oleh & warga \\
Negara biasa & \\
\end{tabular} \\
\hline
\end{tabular}

Berdasarkan beberapa defenisi partisipasi politik diatas, dapat dicermati bahwa setiap partisipasi politik yang dilakukan oleh masyarakat merupakan kegiatan-kegiatan sukarela yang nyata dilakukan, tanpa menekankan pada sikap-sikap tetapi pada tujuan setiap tindakan tersebut.

Bentuk-bentuk partisipasi politik merupakan serangkaian pilihan kegiatan yang berkaitan dengan keikutsertaan dalam kehidupan politik. Meskipun bentuk-bentuk partisipasi politik yang dikemukakan para sosiolog tidak dapat diterapkan pada semua negara, tetapi secara garis besar bentukbentuk partisipasi politik tersebut memiliki kesamaan persepsi.

Rush dan Althoff, mengemukakan bentuk-bentuk partisipasi politik ke dalam tingkatan-tingkatan/hierarki sebagai berikut: Menduduki jabatan politik atau administratif, mencari jabatan politik atau administratif, keanggotaan aktif 
suatu organisasi politik, keanggotaan pasif suatu organisasi politik, keanggotaan aktif suatu organisasi semu politik (quasi political),keanggotaan pasif suatu organisasi semu politik (quasi political),partisipasi dalam rapat umum, demonstrasi dan sebagainya,partisipasi dalam diskusi politik, dan voting atau pemberian suara. Hierarki partisipasi politik yang dikemukakan Rush dan Althoff digambarkan sebagai berikut:

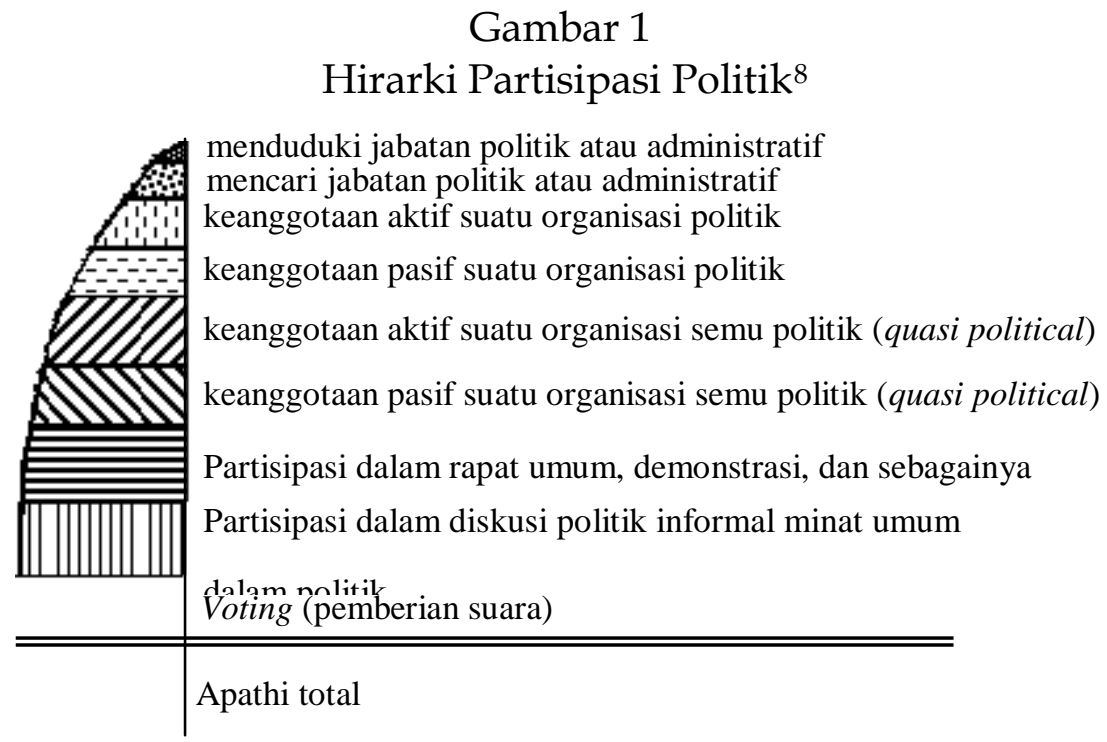

Hierarki partisipasi politik yang dikemukakan Rush dan Althoff menunjukkan bahwa pada puncak hierarki terdapat orang-orang yang menduduki jabatan dalam sistem politik termasuk anggota birokrat pada berbagai tingkatan. Kelompok yang menduduki hierarki tertinggi memiliki kepentingan yang besar terhadap pelaksanaan kekusaan politik yang formal. Dalam pelaksanaan kekuasaan politik, bukan berarti terlepas dari pengaruh individu-individu atau kelompok-kelompok lain dalam sistem politik termasuk individu atau kelompok yang mencari jabatan politik.

Pada tingkatan di bawah orang-orang atau kelompok-kelompok yang mencari jabatan politik terdapat keanggotaan pada organisasi politik kelompok kepentingan. Perbedaan yang paling mendasar antara partai politik dengan kelompok kepentingan terletak dari persepsi mereka terhadap politik. Kelompok kepentingan adalah organisasi yang berusaha memajukan, mempertahankan, atau mewakili sikap-sikap yang terbatas. Setelah tujuan atau maksud mereka tercapai, apakah dalam waktu singkat ataupun berkesinambungan, kelompok ini tidak memaksakan diri untuk terlibat dalam sistem. Sedangkan partai politik berusaha memajukan, mempertahankan, dan mewakili aspek yang lebih luas. Oleh sebab itu, pendukung partai politik lebih luas dibandingkan pendukung kelompok kepentingan.

8 Michael Rush dan Phillip Althoff, An Introduction to Political Sociology, diterjemahkan Pengantar Sosiologi Politik (RajaGrafindo Persada, Jakarta, 2003). hal. 122. 
Ketidakterlibatan individu pada partai politik memiliki alasan sendiri, tetapi bukan berarti mereka sama sekali tidak melibatkan diri dalam partisipasi politik apapun. Dalam diskusi-diskusi atau seminar yang membicarakan politik sering ditemukan individu-individu yang bukan orang partai tetapi intens mengikuti perkembangan politik, terlepas apakah kehadirannya karena difasilitasi partai politik itu atau kelompok kepentingan tertentu.

Bentuk partisipasi politik yang tidak intens (kadang-kadang) adalah diskusi-diskusi informal. Bentuk partisipasi politik cenderung melibatkan sejumlah orang, baik dalam keluarga, teman kerja, teman sekolah, maupun teman sebaya. Intensitas diskusi informal ini tergantung pada kondisi perpolitikan yang sedang berkembang. Makin menarik kondisi politik yang sedang berkembang, makin intens diskusi informal ini berlangsung.

Karakteristik individu juga berperan dalam pilihan bentuk partisipasi politik. Terdapat orang-orang yang tidak mau berdiskusi dengan orang mengenai persepsi politiknya secara lisan, tetapi bukan berarti mereka tidak tertarik dengan politik. Dalam kondisi ini, peran media massa dalam memberikan informasi-informasi politik sangat besar peristiwa politik yang telah, sedang, dan akan terjadi.

Tingkatan hierarki terendah adalah voting atau pemberian suara karena bentuk partisipasi ini menuntut keterlibatan minimal masyarakat. Jika proses pemberian suara selesai, maka partisipasi politik juga berhenti seketika.

Rush tidak menampik kemungkinan adanya bentuk partisipasi politik lain seperti kekerasan dan keasingan, tetapi tidak dimasukkan dalam tingkatan atau hieraki partisipasinya. Tidak dimasukkannya kekerasan dan keasingan merupakan bentuk kehati-hatian Rush, termasuk tidak memasukkan apati atau kepasifan pada bentuk aktifitas politik, meskipun untuk apati masih ada keraguan apakah apati hanya pada bentuk partisipasi politik tertentu atau pada seluruh bentuk partisipasi politik. Affan Gaffar dalam Syarofin mengkategorikan partisipasi politik ke dalam bentuk-bentuk ${ }^{9}$ :

a. Electoral activity, yaitu segala bentuk kegiatan yang secara langsung maupun tidak langsung berkaitan dengan pemilu. Termasuk dalam kategori ini adalah ikut serta dalam memberikan sumbangan untuk kampanye sebuah partai, menjadi sukarelawan dalam kegiatan kampanye sebuah partai politik, ikut mengambil bagian dalam kampanye atau rally politik sebuah partai, mengajak seseorang untuk mendukung dan memilih suatu partai politik atas nama partai itu, memberikan suara dalam pemilu, mengawasi pelaksanaan pemberian dan penghitungan suara, menilai calon-calon yang diajukan, dan sebagainya.

b. Lobyying, yaitu tindakan seseorang atau sekelompok orang untuk menghubungi pejabat pemerintah ataupun para tokoh politik dengan tujuan untuk mempengaruhi pejabat atau tokoh politik tersebut yang menyangkut masalah tertentu tentang yang mempengaruhi kehidupan mereka. Kegiatan ini biasa dilakukan untuk mendapatkan dukungan

\footnotetext{
${ }^{9}$ Affan Gaffar, Beberapa Aspek Pembangunan Politik (Rajawali Press, Jakarta. 1998), hal. 243
} 
terhadap masalah tertentu yang hendak ditangani oleh pemerintah atau lembaga perwakilan rakyat.

c. Organizational activity, yaitu keterlibatan warga masyarakat ke dalam berbagai organisasi sosial politik, baik sebagai pimpinan, aktifis maupun anggota biasa

d. Contacting, yaitu partisipasi yang dilakukan warga Negara dengan secara langsung pejabat pemerintah atau tokoh politik baik dilakukan secara individual maupun kelompok dalam jumlah kecil.

e. Violence, yaitu cara-cara kekerasan untuk mempengaruhi pemerintah biasanya berupa pengrusakan.

Dari bentuk-bentuk yang dikemukakan, secara umum partisipasi politik terdiri dari dua bentuk, yakni : Pertama, bentuk partisipasi politik konvensional yang meliputi pemberian suara dalam pemilu, kampanye politik, petugas dalam pemilihan, sukarelawan dalam kegiatan kampanye, diskusi politik baik formal maupun informal, keterlibatan pada organisasi sosial politik, dan menduduki jabatan politik dan administrasi. Kedua, bentuk partisipasi politik non konvensional yang meliputi, apatis, contacting dan violence.

\section{Partisipasi Politik dan Pilihan Rasional}

Fenomena meningkatnya partisipasi politik masyarakat, serta sejumlah kasus kejiwaan akibat dampak kegagalan menduduki jabatan politis menimbulkan pertanyaan mendasar dari motivasi individu terlibat dalam aktivitas politik. Mengacu pada pandangan Teori Tindakan Rasional dari Cooleman, dengan unsur utama yakni; aktor dan sumber daya, terdapat korelasi dalam memotivasi individu pemenuhan hasrat politiknya.

\section{a. Aktor}

Aktor merupakan pelaku dari tindakan politik yang dipengaruhi oleh tujuan, pertimbangan, dan motivasi tertentu sehingga mempengaruhi sikap dan pilihan-pilihannnya. Sebagaimana dalam Teori Pertukaran yang mempengaruhi Teori Pilihan Rasional, bahwa manusia terus menerus terlibat dalam memilih diantara perilaku-perilaku alternatif, dengan pilihan mencerminkan cost and reward (biaya dan ganjaran) yang dihargai pihak-pihak yang terlibat ${ }^{10}$. Pada pertukaran tersebut, terdapat pihak yang memperoleh keuntungan bukan hanya dalam bentuk materi tetapi juga non materi.

Pada pengelolaan pencapaian tujuan, individu didorong adanya kebutuhan yang memunculkan semangat dalam menentukan pilihan. Hal tersebut tidak terlepas dari motivasi politik yang mendorong dalam pencapaian tujuan tersebut sebagai sebuah kebutuhan. Abraham Harold Maslow menyatakan bahwa manusia dimotivasi oleh berbagai kebutuhan dan keinginan ini muncul dalam urutan hirarki, dan mengidentifikasi dalam urutan yang semakin meningkat sebagai berikut; 11 a).Kebutuhan Fisiologis (Physiological Needs).b). Kebutuhan Keamanan dan Keselamatan Kerja (Safety $\mathcal{E}$

\footnotetext{
${ }^{10}$ Damsar, Pengantar Teori Sosiologi (Kencana; Jakarta, 2017), hal. 160

${ }^{11}$ Handoko, Manajemen Personalia dan Sumber Daya Manusia (BPFM; USM, 1991), hal. 255
} 
Securtiy Needs). c) Kebutuhan Sosial (Social Needs), d) Kebutuhan Penghargaan ( Esteem Needs), dan e). Kebutuhan Aktualisasi Diri (Self-Actualization Needs)

Menurut Henry Murray (Usmara, 2006: 53) percaya bahwa kebutuhan diperoleh melalui interaksi individu dengan lingkungan. Murray mengembangkan daftar kebutuhan yang sangat panjang. Mc Clelland secara khusus tertarik pada salah satu kebutuhan yang dikemukakan oleh Murray yaitu kebutuhan untuk berprestasi. Mc Clelland merasa bahwa kebutuhan berprestasi merupakan kebutuhan yang diperoleh, yang dikembangkan sejak kecil sebagai hasil dari dorongan dan kepecayaan pada diri sendiri oleh orang tua. Dia juga berpendapat bahwa hal tersebut dapat juga diajarkan pada saat dewasa. Mc Clelland berpendapat bahwa manusia dengan kebutuhan prestasi yang tinggi dibagi ke dalam beberapa karakteristik sebagai berikut ${ }^{12}$;

a) Keinginan yang kuat untuk tanggung jawab pribadi.

b) Keinginan timbal balik yang cepat dan konkret dengan mempertimbangkan hasil dari pekerjaan mereka.

c) Melakukan pekerjaan dengan baik, penghargaan moneter dan materi lainnya berhubungan dengan prestasi.

d) Kecenderungan untuk mengatur tujuan prestasi yang layak.

e) Manusia dengan kebutuhan prestasi yang kuat akan menghasilkan tingkat pencapaian tujuan yang tinggi.

f) Suka mengambil tanggung jawab untuk menyelesaikan masalah.

g) Menentukan target-target pencapaian yang masuk akal.

h) Mengambil resiko-resiko dengan penuh perhitungan.

i) Berkemauan keras untuk memperoleh umpan balik atas kinerjanya.

j) Mc Clelland beranggapan bahwa kebutuhan prestasi dapat dikembangkan pada orang dewasa. Manusia yang dewasa emosional akan jauh lebih mampu memotivasi dirinya

Motivasi terkait dengan kebutuhan, baik yang dikemukakan Malinowski maupun Mc Clelland menunjukkan bahwa setiap individu pada dasarnya memiliki kesadaran diri untuk melakukan tindakan berdasarkan tujuan tertentu dengan se rasional mungkin. Pada aspek politik, individu membutuhkan segala aspek yang dikemukakan Malinowski dan Mc Clelland dimana pencapaian tujuan politik akan menjamin khususnya kebutuhan finansial, kebutuhan sosial, aktualisasi diri, dan prestise (penghargaan). Pada konteks ini, individu akan mempertimbangkan hasil dari pilihan dan target pencapaiannya melalui pilihan terhadap bentuk partisipasi politik secara rasional. Oleh sebab itu, setiap individu akan memilih bentuk partisipasi politik sesuai dengan tujuan politiknya. Pada satu sisi individu akan berupaya mencapai popularitas politik, dan di sisi lain individu lain lebih memilih bentuk partisipasi politik terendah yaitu memberi suara pada pemilihan umum.

\section{b. Sumber daya}

Sumber daya merupakan potensi yang dimiliki aktor, dan sumber daya di

\footnotetext{
${ }^{12}$ Usmara, Motivasi Kerja : Proses, Teori, dan Praktik (Amara Books. Yogyakarta2006), hal. 53.
} 
luar potensi diri serta dapat dikendalikan berdasarkan tujuan aktor. Potensi diri yang dimiliki aktor merupakan serangkaian faktor-faktor yang mendukung pilihan rasional aktor. Sedangkan sumber daya di luar potensi diri merupakan faktor pendukung eksternal dalam penetapan pilihan politik aktor.

Mencapai tujuan politik, tidak terlepas dari modalitas politik sebagai sumber daya eksternal yang harus dimiliki individu. Politik sebagai arena pertarungan strategi tidak hanya membutuhkan keinginan semata, tetapi membutuhkan modal finansial yang besar, modal jaringan yang luas, popularitas yang tinggi, partai politik yang memperoleh simpati masyarakat, dan dukungan negara dalam bentuk regulasi.

Dari seluruh proses politik dan sistem politik yang melingkupi realitas politik reformasi saat ini, individu diberi keleluasaan (motivasi politik) untuk berkreasi dan memformulasikan cara-cara meraih kekuasaan menurut makna yang dilabelkan terhadap kekuasaan. Dinamika partai politik yang kompleks, ikut menawarkan sisi kehidupan lain dimana kekuasaan sangat erat dengan pencapaian segala aspek kehidupan sosial termasuk eksistensi peran dan status dalam masyarakat. Keterlibatan individu dalam aktifitas politik tidak lagi hanya bersentuhan dengan pemenuhan hak individu sebagai bagian dari pelaku proses pembangunan, tetapi mengarah pada pencapaian simbol-simbol status yang diringi dengan pemuasan kesenangan dan kenikmatan.

Partai politik sebagai media atau sarana penyaluran libido politik (libido kekuasaan) menyediakan trik-trik pembangkit libido (istilah Piliang) yang pada dasarnya berfungsi sebagai pembangkit libido atau hasrat kekuasaan individu dan masyarakat. Eksistensi partai politik dan hasrat politik yang dimiliki setiap personal berbanding lurus dalam menciptakan harmonisasi relasi. Kondisi personal individu sangat berperan penting bagaimana proses libidonisasi (politik konsumsi) dalam diri seseorang dapat menguasai dirinya, sebagai hasil dari pilihan rasionalnya.

\section{PENUTUP}

1. Teori Pilihan Rasional dari James S Coleman merupakan salah satu teori yang menekankan pada tindakan perseorangan yang mengarah pada suatu tujuan yang ditentukan oleh nilai atau preferensi (pilihan). Teori ini mendapat pengaruh dari Teori Pertukaran, bahwa individu dalam menentukan pilihan tindakan, telah mempertimbangkan cost dan reward yang diperoleh dari tindakan tersebut. Pertimbangan cost dan reward menunjukkan bahwa individu secara rasional dengan kesadaran dirinya mampu memperhitungkan pencapaian target yang telah ditentukannya.

2. Aktor dan Sumber Daya sebagai unsur utama Teori Pilihan Rasional, merupakan dua entitas yang mendorong minat hasrat politik individu. Aktor sebagai pelaku tindakan (partisipasi politik) menggunakan segenap sumber daya internal dan eksternal dalam pencapaian tujuan politiknya. Sumber daya eksternal yang meliputi modalitas politik 
menjadi pertimbangan individu dalam menentukan bentuk partisipasi politik yang secara rasional dianggap tepat.

\section{DAFTAR PUSTAKA}

Al Qhardawi, Yusuf, Membumikan Syariat Islam, Dunia Ilmu: Surabaya, 1997.

Budhiardjo, Miriam, Partisipasi dan Partai Politik, Jakarta: PT.Gramedia, 1982.

Damsar, Pengantar Teori Sosiologi, Kencana; Jakarta, 2017.

Gaffar, Affan, Beberapa Aspek Pembangunan Politik, Rajawali Press, Jakarta. 1998.

Handoko, Manajemen Personalia dan Sumber Daya Manusia, BPFM; UGM, 1991.

Mas'oed, Mochtar, Negara, Kapital dan Demokrasi, Yogyakarta: Pustaka Pelajar, 2003.

Ritzer, George, dan Douglas J. Goodman, Teori Sosiologi Modern, Edisi Revisi. Yogyakarta: Kreasi Wacana, 2012.

Ritzer, Goerge, Encyclopedia of Social Theory, United Kindom America; SAGE Publication, 2004.

Rush, Michael dan Phillip Althoff, An Introduction to Political Sociology, diterjemahkan Pengantar Sosiologi Politik, RajaGrafindo Persada, Jakarta, 2003.

Usmara, Motivasi Kerja: Proses, Teori, dan Praktik, Amara Books. Yogyakarta, 2006. 